\title{
UZNANIE ZA PRACOWNIKA OSOBY ZATRUDNIONEJ NA PODSTAWIE UMOWY CYWILNOPRAWNEJ
}

\begin{abstract}
Streszczenie. Autor analizuje koncepcję pracownika wypracowaną w orzecznictwie Trybunału Sprawiedliwości UE (TSUE). Akcentuje autonomiczny charakter definicji „pracownika”, pod którym to pojęciem TSUE rozumie osoby świadczące pracę na podstawie umów cywilnoprawnych oraz samozatrudnione. Przedstawia kryteria stosowane w judykaturze unijnej pozwalające odróżnić zatrudnienie pracownicze od niepracowniczego. Podkreśla przepisy prawa pracy, materialne i procesowe, pozwalające zainteresowanym na uznanie za pracownika osoby zatrudnionej w ramach umów cywilnoprawnych.
\end{abstract}

Słowa kluczowe: pracownik, pracodawca, samozatrudniony, stosunek pracy, umowa cywilnoprawna, usługa, zatrudniony.

\section{WPROWADZENIE}

Przedmiotem rozważań jest sytuacja osób świadczących pracę na podstawie i w ramach umów cywilnoprawnych. Nietypowe formy zatrudnienia oraz status prawny osób wykonujących pracę na podstawie umów regulowanych przepisami prawa cywilnego jest przedmiotem zainteresowania zarówno w Polsce, jak i w Unii Europejskiej. Według projektu nowelizacji dyrektywy Rady UE 91/533/EWG z 14.04.1991 r. w sprawie obowiązku pracodawcy dotyczącego informowania pracowników, stosowanych do umowy o pracę lub stosunku pracy (Written Statement Directive, Dz.Urz. L 288 z 18.10.1991, s. 32), ochroną prawną i socjalną powinien być objęty każdy zatrudniony. Realizując unijny program „Europejski Filar Praw Społecznych" (European Pillar of Social Rights), Komisja UE przedstawiła 21.12.2017 r. projekt dyrektywy o przejrzystości i przewidywalności warunków zatrudnienia (Directive on Transparent and Predictable Working Conditions) $)^{1}$. W art. 2 ust. 1 powyższego projektu sformułowana została prawna definicja beneficjenta. Jest nim „zatrudniony” (worker), „osoba fizyczna świadcząca przez pewien okres usługi na rzecz i pod kierownictwem innej osoby w zamian za wynagrodzenie".

* Akademia Ignatianum w Krakowie, Wydział Pedagogiczny, Instytut Nauk o Polityce i Administracji, andrzej.swiatkowski@uj.edu.pl

${ }^{1}$ Dyrektywa Parlamentu Europejskiego i Rady (UE) 2019/1152 z dnia 20.06.2019 r. w sprawie przejrzystych i przewidywalnych warunków pracy w Unii Europejskiej (Dz.Urz. UE L.186/105) zastąpi od 1.08.2022 r. dyrektywę 91/533/EWG. 


\section{PRACA JAKO USLUGA}

Praca w znaczeniu prawnym może być przedstawiana jako usługa. Tytuł XI „Umowy o świadczenie usług”, Dział I. „Umowa o pracę” Kodeksu zobowiązań regulował warunki pracy wykonywanej w ramach umowy o pracę (rozporządzenie Prezydenta Rzeczypospolitej z 27.10.1935 r., Dz.U. 82/33, poz. 598). Poza umową o pracę do grupy umów o świadczenie usług zakwalifikowane zostały przez polskiego ustawodawcę między innymi umowy o dzieło, zlecenie, pośrednictwo, przechowanie. Wspólną cechą tych umów był ich przedmiot - ,świadczenie usług dla drugiego”, pod którym to pojęciem wówczas rozumiano „czynność ludzką, która zdoła zaspokoić potrzeby drugiego" (człowieka)². W uzasadnieniu wyraźnie stwierdzono, że przepisy dotyczące umów o pracę (Rozdz. I „Przepisy ogólne”, art. 441-446; Rozdz. II „Obowiązki stron”, art. 447-465; Rozdz. III „Zakończenie stosunku pracy”, art. 466-475; Rozdz. IV „Przejście zakładu pracy na inną osobę", art. 476 k.z.) oraz rozporządzeń dotyczą „tylko pracy zależnej” (Bloch, 1936). Uchwalone w II RP przepisy prawa pracy (rozporządzenie prezydenta RP z 16.03.1928 r. o umowie o pracę pracowników umysłowych, Dz.U. 35/28, poz. 192) za pracowników uważały osoby wykonujące czynności nadzorcze i administracyjne wymienione w art. 2 pkt $1-9$. Przeto nie podstawa zatrudnienia, ale charakter i rodzaj wykonywanej pracy miały decydujące znaczenie $\mathrm{w}$ procesie klasyfikacji zatrudnienia regulowanym przepisami rozporządzenia o umowie o pracę pracowników umysłowych lub drugiego rozporządzenia Prezydenta RP z 16.03.1928 r. o umowie o pracę robotników (Dz.U. 35/28, poz. 324). Robotnikami w rozumieniu art. 2 tego drugiego rozporządzenia byli „pracownicy zatrudnieni na podstawie umowy o pracę, z wyjątkiem - między innymi - pracowników umysłowych". Po raz pierwszy w polskim prawie pracy podstawa zatrudnienia - umowa o pracę, stanowiąca podstawę i ramy prawne zobowiązaniowego stosunku pracy, została wymieniona w akcie prawnym regulującym warunki pracy robotników.

\section{DYFERENCJACJA STATUSU ZATRUDNIONYCH}

W zmienionym ustroju ustawodawca zlikwidował podziały zatrudnionych na pracowników umysłowych i robotników oraz zdefiniował w art. 2 Kodeksu pracy osoby zatrudnione $\mathrm{w}$ ramach stosunku pracy - czyli pracowników. Data wejścia w życie - 1.01.1975 r. - obowiązującego Kodeksu pracy (ustawa z 26.06.1974 r., t. jedn. Dz.U. z 2018 r., poz. 917 ze zm.) stanowi cezurę podziału

${ }^{2}$ Objaśnienia do projektu (części szczegółowej) prawa o zobowiązaniach autorstwa prof. Tilla i prof. Longchamps de Berier. Uzasadnienie projektu Kodeksu zobowiązań autorstwa prof. Longchamps de Berier. Wyd. Komisji Kodyfikacyjnej, z. 82, 85, 88. 
zatrudnienia na pracownicze i niepracownicze. W tej drugiej grupie mieszczą się między innymi stosunki pracy nawiązanej na podstawie umów cywilnoprawnych: umowy zlecenia, o świadczenie usług, agencyjnej, o dzieło oraz kontraktów menedżerskich zawieranych z osobami zatrudnionymi w sferach publicznej i prywatnej (Świątkowski 2015). Problem zatrudnienia w charakterze nie-pracowników nabrał znaczenia od momentu korzystania przez pracodawców $\mathrm{z}$ nietypowych - dotąd stosunkowo rzadko stosowanych w stosunkach pracy - metod i technik zatrudnienia, takich jak działalność gospodarcza prowadzona na własny rachunek, a więc samozatrudnienie (selfemployment). Ponadto nowe, innowacyjne formy zatrudnienia - stosowane coraz częściej w gospodarczo rozwiniętych państwach unijnych oraz w Wlk. Brytanii i innych państwach na świecie, w ramach programów gig economy, platform zatrudnienia, nowych technologii, jak sztuczna inteligencja, automaty i roboty zastępujące pracę wykonywaną przez człowieka - sprawiają, że coraz częściej naukowcy zajmujący się prawem pracy zaczynają zastanawiać się nad wykorzystaniem w sposób jak najbardziej efektywny innowacyjnych metod stosowania prawa dla zahamowania, a następnie przeciwdziałania postępującej i rosnącej globalnej fali zjawiska prekaryzacji (Świątkowski 2018). Na unijnym rynku pracy zauważalni są ludzie W wieku aktywności zawodowej - prekariuszki i prekariusze - pozbawieni perspektyw życiowych i zawodowych. We współczesnym świecie w opinii państw Unii Europejskiej podstawową sprawą jest poprawa warunków zatrudnienia wszystkich osób wykonujących pracę zarobkową. W pierwszym rzędzie chodzi o powszechną stabilizację zatrudnienia, poprawę warunków pracy i wynagrodzenia oraz świadczenia z zabezpieczenia społecznego dla osób niezaliczanych przez przepisy prawa pracy państw członkowskich UE do kategorii pracowników. Teoretycznie zmiana status quo osób zatrudnionych w krajach Unii „nie-pracowniczo" może nastąpić poprzez uchwalenie i wprowadzenie w życie nowych przepisów prawa pracy. Takim przykładem jest wymieniony na wstępie niniejszego opracowania projekt dyrektywy z roku 2017. Powstał on w ramach unijnego programu modernizacji prawa pracy (Świątkowski 2015) ${ }^{3}$. Projekt owej dyrektywy, aprobowany przez Konfederację Europejskich Związków Zawodowych (European Trade Union Confederation - ETUC) ${ }^{4}$, został jednak odrzucony przez ponadnarodowe organizacje pracodawców i przedsiębiorców działających w przestrzeni unijnej ${ }^{5}$. Autorom projektu dyrektywy zarzucono między innymi naruszenie fundamentalnej zasady subsydiarności i pomocniczości (art. 5 Traktatu o Unii Europejskiej - TEU). Z tego względu w piśmiennictwie unijnego

\footnotetext{
${ }^{3}$ Green Paper „Modernizing Labour Law to meet the challenges of the $21^{\text {st }}$ Century”. $\operatorname{COM}(2006) 708$ final.

${ }^{4}$ ETUC position on the draft Transparent and Predictable Working Conditions Directive, adopted at the Executive Committee Meeting of 7-8 March 2018.

${ }^{5}$ UEAPME position on a proposal for a directive on transparent and predictable working conditions in the European Union. Com(2017)797. Brussels, 26.02.2018.
} 
prawa pracy zaczęto rozważać możliwość ochrony prawnej i socjalnej osób pracujących, niekorzystających w państwach członkowskich UE z ochrony prawnej i socjalnej gwarantowanej pracownikom.

\section{REDEFINICJA UNIJNEGO POJECIA PRAWNEGO „PRACOWNIK”}

W polskiej literaturze traktującej o prawie pracy Unii Europejskiej już kilka lat temu stwierdzono, że uprawnienia gwarantowane przepisami pierwotnego prawa unijnego - TUE oraz Traktatu o Funkcjonowaniu Unii Europejskiej (TFUE) - przysługują wszystkim osobom zatrudnionym, a nie tylko pracownikom (Świątkowski 2014). W związku z powyższym zasygnalizowana została konieczność dokonania w polskim systemie prawa pracy unifikacji uprawnień osób aktywnych zawodowo, wykonujących pracę w ramach stosunku pracy, zatrudnionych na podstawie umów cywilnoprawnych oraz osób samozatrudnionych. Dwie ostatnie kategorie powinny obejmować pracujących osobiście podległych osobom zatrudniającym i ekonomicznie od nich zależnym. Instytucje unijne dostrzegły szansę weryfikacji, skonstruowanej w judykaturze Trybunału Sprawiedliwości UE (TSUE), autonomicznej, bardziej pojemnej i nowocześniejszej definicji pracownika. Jednakowoż reakcja unijnych przedsiębiorców na powyższą inicjatywę była negatywna ${ }^{6}$. W Polsce zastosowana przez TSUE innowacyjna metoda wykładni definicji prawnej ,pracownika” została dostrzeżona i wykorzystana przez Trybunał Konstytucyjny (TK), który pozytywnie wypowiedział się o możliwości korzystania z wolności związkowej gwarantowanej przepisami ustawy o związkach zawodowych z 23.05.1991 r. (t. jedn. Dz.U. z 2015 r., poz. 1881 ze zm.) przez wszystkich zatrudnionych (wyrok TK z 2.06.2015 r., K 1/13, Dz.U. z 2015 r., poz. 791) (zob. Świątkowski 2016, 8 i n.; Musiała 2017, 173 i n.). Uznając za niezgodne z Konstytucją przepisy ustawy o związkach zawodowych, ograniczające wolność tworzenia i wstępowania do związków zawodowych osobom wykonującym pracę zarobkową $\mathrm{w}$ innych formach i ramach prawnych zatrudnienia aniżeli pracownicze, TK powołał między innymi przepisy Europejskiej Konwencji Praw Człowieka (Dz.U. z 1993 r., nr 61, poz. 284), która w art. 11 ust. 1 wyraźnie stanowi, iż wolność zrzeszania się przysługuje każdej osobie. W przypadku osób zawodowo aktywnych, z powyższej swobody mają prawo korzystać wszyscy pracujący (Świątkowski 2015).

$\mathrm{Na}$ temat następstw prawnych stosowania w krajowym prawie pracy angielskiego określenia worker wypowiedziała się A. Musiała (2018). Wyprowadziła ona trafny wniosek, iż w angielskim pojęciu worker mieszczą się zarówno pracownicy, jak i niektórzy samozatrudnieni. Nie posłużyła się definicją prawną „pracownika” sformułowaną w brytyjskich aktach prawnych (Trade Union and Labour Relations

\footnotetext{
${ }^{6} \operatorname{COM}(2017) 797$ final.
} 
Act - TULRA) i słowniku oficjalnych terminów prawa pracy. W wymienionych dokumentach pod określeniem worker rozumie się osoby trudniące się pracą „własnych rąk" (manual worker), w celu zaznaczenia różnic wobec osób niewykonujących takiej pracy (non-manual paid work). W ustawie z 1974 r. (TURLA) zdefiniowano pojęcie worker jako zatrudnionego na podstawie umowy o pracę lub innej umowy zawartej w celu osobistego świadczenia pracy przez zatrudnionego przy wykonywaniu jakiejkolwiek pracy albo usług, innych niż te świadczone na rzecz professional client. W tej definicji mieści się również praca wykonywana przez osobę pracującą na własny rachunek (samozatrudnionego) (Terry, Dickens 1991). W nowszej literaturze prawniczej termin worker jest wyprowadzany z terminologii obowiązującej pod koniec XIX i na początku XX stulecia - określenia workman używano wtedy dla oznaczenia osoby utrzymującej się wyłącznie z pracy fizycznej (McCrudden 2012). Według obowiązującego wówczas aktu prawnego - Employment Relations Act (ERA 1996, sec. 230(3)) - pojęcia worker używano dla określenia osoby (individual) wykonującej osobiście (personally) jakąkolwiek pracę albo świadczącej usługi na rzecz drugiej strony umowy na podstawie umowy o pracę (employment contract) lub jakiejkolwiek innej umowy (any other contract), niewystępującej w roli klienta (client, customer) lub jednoosobowego przedsiębiorcy bądź osoby prowadzącej inne przedsięwzięcie. Rozbudowana definicja osoby zatrudnionej ma umożliwić odróżnienie osoby samozatrudnionej zależnej, występującej wyłącznie na rynku pracy od samozatrudnionego funkcjonującego na rynku usług. Ten ostatni może stanowić, w odróżnieniu od pierwszego, konkurencję dla przedsiębiorcy działającego na rynku usług. Moim zdaniem, najbardziej istotną cechą decydującą o uznaniu samozatrudnionego za pracującego (worker) w rozumieniu unijnych przepisów prawa pracy jest potencjalna możliwość lub jej brak konkurowania na wspólnym rynku osoby zatrudnionej z osobą zatrudniającą pracowników. Samozatrudniony, niemający możliwości ani szans konkurowania z innym przedsiębiorcą na wspólnym rynku, może więc być zakwalifikowany do kategorii worker - obejmującej osoby zatrudnione i pracujące („ludzi pracy”). Współcześnie bowiem zakres tego określenia jest szeroki. Mieszczą się w nim pracownicy, zatrudnieni, pracujący oraz osoby odbywające praktyki zawodowe poprzedzające nabycie uprawnień koniecznych do uzyskania uprawnień zawodowych w określonym fachu.

\section{KRYTERIA WYPRACOWANE W JUDYKATURZE UNIJNEJ DLA ODRÓŻNIENIA ZATRUDNIENIA PRACOWNICZEGO OD NIEPRACOWNICZEGO}

W aktach unijnego prawa pierwotnego termin zatrudniony, pracujący (worker) nie był bezpośrednio związany ze świadczeniem jakiejkolwiek pracy, lecz $\mathrm{z}$ potrzebą swobodnego przemieszczania się w obrębie wspólnego rynku. Z tej 
przyczyny został wymieniony w traktatach tylko w dwóch przepisach TFUE - art. 45 ust. 1 gwarantującym swobodę przepływu osób oraz art. 157 ust. 1 normy zobowiązującej do przestrzegania zasady równego traktowania - bez względu na płeć - w sprawach odnoszących się do zapłaty wynagrodzenia osób zatrudnionych. Wymienione przepisy gwarantują ochronę prawną na wspólnym rynku wszystkim obywatelom państw członkowskich UE aktywnym zawodowo. W okresach poprzedzających nabycie pełnych uprawnień wynikających z przynależności określonego państwa do UE, ze swobody przemieszczania się nie korzystali natomiast przez pewien czas jedynie pracownicy. Inne osoby zatrudnione świadczące usługi (w tym także samozatrudnieni) korzystały z nieograniczonej wolności podróżowania i prowadzenia działalności zarobkowej. Równy, nieograniczony dostęp do wspólnego rynku, z jakiego mają prawo korzystać przedsiębiorcy, różnił się od uprawnień, na jakie powinni móc liczyć pracownicy i inne osoby osobiście świadczące pracę na rzecz pracodawcy i pod jego kierownictwem. W początkowym okresie obywatele państw członkowskich usytuowanych przez przepisy unijne w okresie przejściowym nie mieli potrzeby korzystania z uprawnień pracowniczych i socjalnych, albowiem do czasu upływu okresu przejściowego nie mieli prawa swobodnego przemieszczania się w administracyjnych ramach państw członkowskich wchodzących w skład UE. Wobec przedsiębiorców natomiast świadczących usługi na wspólnym rynku, również osób samozatrudnionych, nie wolno było stosować ograniczeń w swobodzie przemieszczania się.

Po raz pierwszy TSUE zinterpretował pojęcie ,,pracownik” (worker) w sprawie Lawrie Blum (C-66/85, Deborah Lawrie Blum versus Land Baden Würtemberg, EU:C:1986:284, § 17). Orzekł wtedy, że charakterystycznymi cechami stosunku pracy jest świadczenie pracy przez okres uzgodniony przez strony na rzecz i pod kierownictwem innej osoby w zamian za wynagrodzenie za pracę. Pierwszą cechą zatrudnienia regulowanego przepisami prawa pracy była zatem aktywność gospodarcza (economic activity). Ta cecha jest także charakterystyczna w przypadku prawa przedsiębiorczości gwarantowanej art. 49 TFUE. Swoboda przedsiębiorczości obejmuje bowiem ,podejmowanie i wykonywanie działalności prowadzonej na własny rachunek”. Koniecznym warunkiem uznania samozatrudnionego za ,pracownika” w rozumieniu art. 45 TFUE było prowadzenie rzeczywistej i prawdziwej (real and genuine) aktywności zawodowej we właściwej skali, nie tylko marginalnej (purely marginal) albo ubocznej (ancillary) (D.M. Levin versus Staatssecretaries van Justice, C-53/81, EU:C:1982:105, $\S 17)$. Te dwa kryteria oraz związane z nimi elementy składowe definicji osoby zatrudnionej w rozumieniu przepisów gwarantujących pracującym swobodę przemieszczania się w ramach wspólnego rynku - wykonywanie pracy i/lub usług na rzecz i pod kierownictwem innej osoby (services for and under the direction of another person) za wynagrodzeniem (remuneration) decydowały o uznaniu albo o odmowie uznania przez TSUE za ,pracownika” w rozumieniu art. 45 TFUE osoby zatrudnionej na podstawie umowy cywilnoprawnej, a w szczególności 
osoby samozatrudnionej. Orzekając według formuły Lawrie Blum TSUE wydał 56 orzeczeń, z których 13 zostało uznanych za precedensowe (Risak, Dullinger 2018). W każdym ze wspomnianych orzeczeń TSUE udzielał odpowiedzi na prejudycjalne pytania prawne przedstawiane przez sądy krajowe państw członkowskich UE w sprawach dotyczących statusu osoby zatrudnionej oraz możliwości jej sklasyfikowania jako zatrudnionego (worker), w rozumieniu wtórnego prawa UE - 14 dyrektyw stanowiących podstawę prawną do przedstawienia hipotezy badawczej na temat roli unijnej judykatury posługującej się autonomiczną definicją „pracownika” w sprawach, w których TSUE określił warunki uznania za „pracownika" (worker) osoby zatrudnionej na podstawie umowy cywilnoprawnej oraz samozatrudnionej. TSUE sformułował unijną autonomiczną definicję pracownika, mimo iż tylko w jednej dyrektywie Rady (89/391/EWG) z 12.06.1989 r. w sprawie wprowadzenia środków w celu poprawy bezpieczeństwa i zdrowia pracowników w miejscu pracy (Dz.Urz. L 183 z 29.06.1989, s. 1) zamieszczono legalną definicję tego pojęcia (pracownika) ${ }^{7}$. W pozostałych 13 dyrektywach za pracowników w rozumieniu przepisów unijnych uznano osoby uważane za pracowników przez władze państw członkowskich UE. Użyto określenia „pracownik” (worker bądź employee), nie definiując znaczenia i zakresu tego terminu albo posługiwano się pojęciami prawnymi „umowa o pracę” lub „stosunek pracy”, nie podejmując próby wskazania podmiotów stosunków i ról, w jakich występują strony tych umów albo stosunków prawnych. Posługując się wypracowaną przez judykaturę unijną „autonomiczną” definicją terminu prawnego worker, można - jak sądzę - uzyskać w miarę solidne i obiektywne podstawy prawne do ustalenia kryteriów uznania w prawie pracy Unii Europejskiej za pracowników (workers) osób zatrudnionych na podstawie umów cywilnoprawnych oraz samozatrudnionych.

\section{RZECZYWISTA I PRAWDZIWA AKTYWNOŚĆ ZAWODOWA}

Niezbędnym warunkiem uznania przez judykaturę unijną aktywności zawodowej osoby zatrudnionej za pracę wykonywaną $\mathrm{w}$ ramach stosunku pracy są stopień zaangażowania pracującego (mierzony ilością czasu poświęconego na pracę wykonywaną na rzecz pracodawcy) oraz (związany z tym istotnym wskaźnikiem dla oceny rodzaju zatrudnienia: pracownicze-niepracownicze) poziom wynagrodzenia w przeliczeniu na godzinę wykonanej pracy. Liczba godzin i wysokość wypłaconego wynagrodzenia decydują o uznaniu przez TSUE za pracownika osoby wykonującej pracę na podstawie umowy cywilnoprawnej lub formalnie osobiście prowadzącej działalność gospodarczą na własny rachunek (samozatrudnionego)

${ }^{7}$ Według art. 3a lit. ,a” Dyrektywy 89/391/EWG pracownikiem jest „,każda osoba zatrudniona przez pracodawcę, włącznie z osobami prowadzącymi szkolenie i praktyki, wyłączając pomoce domowe". 
(C-14/09, Hava Genc versus Land Berlin, EU:C:2010:57, § 27). Ograniczony czas pracy oraz niewielkie zarobki wypłacane pracującemu zobowiązanemu do świadczenia pracy w części dziennej lub tygodniowej standardowych norm czasu pracy są wskaźnikami, że praca może być wykonywana w ramach doraźnej usługi świadczonej przez osobę zatrudnioną na podstawie umowy cywilnoprawnej, a nie przez pracownika zobowiązanego do pracy w pełnym wymiarze norm czasu pracy, dobowej i tygodniowej. Dodatkowym argumentem przemawiającym na rzecz odmowy uznania osoby zatrudnionej za pracownika w rozumieniu unijnych przepisów prawa pracy jest nieregularny charakter zatrudnienia (C-357/89, V.J.M. Raulin versus Minister versus Onderwijs en Wetenschappen, EU:E:1992:87, $\S 14)$. Brak obowiązku przestrzegania przez pracującego zakładowych przepisów o czasie pracy, określonych w regulaminie pracy obowiązującym u pracodawcy zatrudniającego osobę ubiegającą się o uzyskanie statusu pracownika, przemawia przeciwko uznaniu za pracownika osoby pracującej na podstawie umowy cywilnoprawnej. Jedyną okolicznością uzasadniającą uznanie za pracownika osoby nieregularnie zatrudnionej jest sformułowany w umowie, na podstawie której osoba zatrudniona wykonuje pracę, obowiązek stawienia się na wezwanie w miejscu pracy $\mathrm{w}$ celu podjęcia $\mathrm{i}$ świadczenia pracy w wymiarze sprecyzowanym przez zatrudniającego.

Zaprezentowane przykładowo orzeczenia TSUE zostały wydane na podstawie wtórnych przepisów prawa unijnego - dyrektyw będących źródłem unijnego prawa pracy. Bardziej liberalne stanowisko w sprawie uznania za pracownika osób zatrudnionych na podstawie umów cywilnoprawnych, z wyłączeniem osób samozatrudnionych ${ }^{8}$, zajmował TSUE wówczas, gdy problem prawny był związany z gwarantowanym art. 45 TFUE (uprzednio art. 39 TWE) prawem do swobodnego przemieszczania się ,pracowników” w ramach wspólnego rynku. W tych przypadkach ani normy czasu pracy, ani wysokość wynagrodzenia otrzymywanego przez zatrudnionych ubiegających się o możliwość korzystania z przywilejów autonomicznej unijnej definicji ,pracownika” (worker) nie stanowiły przeszkody do uznania za pracownika niemal każdej zawodowo aktywnej osoby. Za „pracowników” w judykaturze uznawano osoby pracujące od 3 do 18 godzin tygodniowo (C-139/85, R.H. Kempf versus Staatssecretaries van Justice, EU:E:C:1986:223, § 16; C-213/05, Wendy Gewen versus Land Nordrhein-Westfalen, EU:C:2005:187, § 27), legitymujące się krótkim, kilkutygodniowym stażem pracy (C-413/01, Franca Ninni-Orasche versus Bundesminister für Wissenschaft, Verkher und Kunst, EU:E:2003:600, §32), pobierające niższe od minimalnego wynagrodzenie za świadczoną pracę. Fakt, że zarobki nie wystarczają na pokrycie kosztów zaspokojenia podstawowych potrzeb osoby chcącej bez ograniczeń przemieszczać się w ramach UE, nie stanowił żadnej przeszkody, aby korzystać z uprawnienia bycia członkiem unijnej

\footnotetext{
${ }^{8}$ Samozatrudnieni, jako osoby świadczące usługi na unijnym rynku usług, korzystali ze swobody przemieszczania niepodlegającej ograniczeniom w okresach przejściowych.
} 
„wspólnoty pracujących” (Risak, Dullinger 2018). TSUE przejął linię orzecznictwa sformułowaną w sprawach odnoszących się do wykładni przepisów prawa pierwotnego (traktatów unijnych) - art. 45 i 157 TFUE w sprawach dotyczących interpretacji wtórnych przepisów - dyrektyw unijnych. Orzekł, że w sprawach o uznanie za pracownika osób zatrudnionych na podstawie umów cywilnoprawnych oraz osób samozatrudnionych nieistotne są takie okoliczności, jak: wydajność pracy, pochodzenie funduszy, z których płacone są wynagrodzenia (C-344/87, I. Bettray versus Staatssecretaries van Justitie, EU:C:1989:226, § 15), stosowane przez zatrudniającego sposoby rekompensaty (wypłata w gotówce, świadczenia w naturze) za wykonywaną pracę (C-456/02, Michel Trojani versus Centre public d'aide sociale de Bruxelles (CPAS), EU:E:C:204:488, § 9). Uznaniu za „pracownika” (worker) w rozumieniu przepisów unijnego wtórnego prawa pracy praktykanta lub stażysty nie przeszkadzało to, że szkolenia, nauka zawodu wszystkich osób, również niepełnoletnich, zostały zorganizowane w sposób umożliwiający praktykującym nabycie rzeczywistych i prawdziwych umiejętności zawodowych (C-109/04, Karl Robert Kranemann versus Land Nordrhein-Westfallen, EU:C:2005:187, §13; C-10/05, Cynthia Matterhn and Hajrudin Cikotic versus Ministre du Travail et de l'Emploi, EU:C:2006:220, §21).

Za istotne wskazówki świadczące o fakcie istnienia pracowniczego zatrudnienia osoby uważanej przez zatrudniającego za samozatrudnionego lub wykonującego usługi w ramach określonej umowy cywilnoprawnej uznawano przyznane zatrudnionemu uprawnienia pracownicze i socjalne, takie na przykład jak: prawo do płatnego urlopu wypoczynkowego (C-432/14, O versus Bio Phillippe Auguste SARL, EU:E:2015: 643, § 25) oraz gwarantowanego wynagrodzenia w okresie nieświadczenia pracy w czasie niezdolności do pracy (ibidem); zagwarantowanie zatrudnionemu uprawnień do świadczeń regulowanych postanowieniami układu zbiorowego pracy (ibidem); objęcie obowiązkiem ubezpieczenia społecznego i opłacanie składek ubezpieczeniowych przez zatrudniającego za zatrudnionego na podstawie umowy cywilnoprawnej, z którą nie łączy się obowiązek opłacania składek przez zatrudniającego (ibidem); nadanie umowie stanowiącej podstawę zatrudnienia, nazwanej kontraktem o świadczenie usług, treści charakterystycznej dla pracy świadczonej w ramach pracowniczego stosunku pracy (C-456/02, Michel Trojani versus Centre public d'aide sociale de Bruxelles (CPAS), EU:E:C:204:488, $\S 17)$ lub mającej cechy zatrudnienia pracowniczego (C-46/12, L.N. versus Styrelsen for Videregăebde Uddannelser og Uddannelsesstøtte, EU:E:C:2013:97, $\S 44)$. W tej ostatniej, sprawie Trojani (C-456/02) TSUE orzekł, że żadna okoliczność uznana za istotną przez krajowy sąd pracy w świetle przepisów prawa pracy państwa członkowskiego UE w postępowaniu o ustalenie pracowniczego statusu osoby zatrudnionej nie ma znaczenia w postępowaniu przed najwyższym unijnym organem wymiaru sprawiedliwości. Zatem ani szczególny charakter stosunku pracy ukształtowany przez system krajowego prawa pracy, ani wydajność pracy czy źródło finansowania wynagrodzenia wypłacanego zatrudnionemu nie 
mają znaczenia w postępowaniu przez sądem unijnym o uznanie za pracownika osoby samozatrudnionej albo świadczącej pracę w ramach jednej z umów cywilnoprawnych.

\section{PRACA (USLUGI) WYKONYWANE ODPLATNIE NA RZECZ I POD KIEROWNICTWEM INNEJ OSOBY}

Charakterystyczną cechą pracy wykonywanej przez pracownika w rozumieniu przepisów unijnych dyrektyw jest podporządkowanie zatrudnionego osobie zatrudniającej, na rzecz której świadczona jest praca. Podporządkowanie pracującego kierownictwu zatrudniającego jest kolejną ważną cechą wykorzystywaną przez unijną judykaturę do odróżnienia zatrudnienia pracowniczego od niepracowniczego (cywilnoprawnego). Nie chodzi tu o kwalifikowanie osoby kierującej pracą pracowników jako właściciela zakładu, w ramach którego i na rzecz którego świadczona jest praca. Kierujący pracą reprezentuje interesy i działa w stosunkach pracy w imieniu osoby lub podmiotu zatrudniającego. W judykaturze unijnej kładzie się nacisk na to, aby pracujący pozostawał pod kontrolą reprezentanta zatrudniającego, uprawnionego do wydawania zatrudnionym poleceń dotyczących sposobu, miejsca i czasu wykonywania pracy (zob. np.: C-3/87, The Quen versus Ministry of Agriculture, Fishieries and Food ex parte Agegate Ltd., EU:C:1989:650, § 36; C-256/01, Debra Allonby versus Accringaton \& Rossendale College and Others, EU:C:2004:18, § 6; C-23/09, Dita Danosa versus LKB Lizings SIA, EU:C:2010:674, § 46; C-47/14, Holterman Ferho Exploitatie BV and Others versus Friedrich Leopold Freiherr Spies von Büllesheim, EU:C:2015:574, § 46; C-229/14, Ender Balkaya versus Kisel Abbruch und Recycling Technik GmbH, EU:C:2015:455, § 37). Zatrudniający lub upoważniona przez niego osoba ma władzę zwierzchnią w procesie zarządzania osobami pracującymi (C-66/55, Lawrie Blum, § 18). Pracownicy są zobowiązani wykonywać jego polecenia dotyczące pracy i warunków jej wykonywania (ibidem). Za szkody wyrządzone nieumyślnie przez pracownika lub z przyczyn przez niego niezawinionych odpowiedzialność ponosi osoba lub podmiot zatrudniający. Pracownik nie partycypuje w ryzyku handlowym, które w całości spoczywa na zatrudniającym go przedsiębiorcy (C-3/87, Agegate, § 36). Pracownik jest obowiązany osobiście świadczyć pracę. Nie ma więc uprawnień do zlecania przypadających nań zadań innym zatrudnionym albo do samodzielnego zatrudniania swoich pomocników (C-270/13, Iraklis Haralambidis versus Calogero Casilli, EU:C:2014:2185, § 33). Bezpośrednią merytoryczną i formalną kontrolę nad pracownikami sprawuje zatrudniający albo wyznaczone przez niego osoby (C-256/01, Alonby, § 72). W stosunku do zatrudnionych nieprzestrzegających powyższych reguł sformułowanych w przepisach prawa pracy osoby sprawujące nadzór nad pracą zatrudnionych są uprawnione do wymierzania kar regulaminowych (C-270/13, Haralambidis, § 30). 
Z powyższej charakterystyki pracowniczych stosunków pracy wynika, iż praca lub usługi, sposób ich wykonywania oraz zasady obowiązujące w miejscu pracy są poddane kontroli osoby lub podmiotu zatrudniającego - pracodawcy. Pracujący są kierowani, kontrolowani i nadzorowani przez osobę zatrudniającą albo jej reprezentantów. Nie mają prawa podejmować decyzji w sprawach dotyczących wyboru miejsca i godzin świadczenia pracy. Nie korzystają ze swobody angażowania pomocników. W miejscu pracy i w czasie wyznaczonym przez zatrudniającego pozostają w kręgu jego władztwa, które zatrudniony ma prawo delegować na inne wybrane i wskazane przez niego osoby. Są w takim stopniu uzależnieni od zatrudniającego, że de facto umowy, na podstawie i w ramach prawnych których świadczą pracę, są traktowane, bez względu na okres zatrudnienia, za fixed-term contracts of employment ${ }^{9}$ (C-22/98, Criminal proceedings against Jean Claude Becu, Annie Verweire, Smeg NV and Adia Interim NV, EU:C:1999:419, § 25). W zamian za tę dyspozycyjność pracujący otrzymują wynagrodzenie i nie partycypują w ryzyku przedsięwzięcia, do którego realizacji zostali zaangażowani.

Zasada podporządkowania pracownika kierownictwu osoby lub podmiotu zatrudniającego ma zastosowanie do osób reprezentujących interesy przedsiębiorców w stosunkach z pracownikami. Kryteria pozwalające na odróżnienie statusu osób sprawujących w imieniu zatrudniającego nadzór nad pracującymi zostały przez unijną judykaturę dostosowane do specyficznej sytuacji, w jakiej znajdują się zatrudnieni wykonujący w imieniu zatrudniającego funkcje kierownicze, nadzorcze i kontrolne w stosunku do osób zatrudnionych w charakterze pracowników. TSUE uważa, że tego rodzaju prace mogą być również wykonywane w ramach zatrudnienia pracowniczego i niepracowniczego. Pozycja osób kierujących zakładem oraz sprawujących nadzór nad pozostałymi zatrudnionymi jest uzależniona od: warunków, na jakich zostali oni zatrudnieni na kierowniczych stanowiskach; zakresu powierzonych im obowiązków i przysługujących im władczych kompetencji; okoliczności, w jakich mogą zostać odwołani z kierowniczych stanowisk, uregulowanych w statutach podmiotów zatrudniających oraz innych dokumentach zaliczanych do kategorii zakładowych źródeł prawa relacji pomiędzy organami zarządzającymi a nadzorującymi określone przedsięwzięcie biznesowe (spółka kapitałowa) albo dobroczynne (fundacja); ich uprawnień w sprawach dotyczących decyzji majątkowych zarządzanej przez nich instytucji (posiadanie akcji). Osoby zarządzające sprawami pracowniczymi mogą bowiem posiadać kompetencje w różnych kategoriach spraw, odnoszących się do sfer: majątkowej, finansowej i organizacyjnej przedsięwzięć, jakimi zarządzają. Decyzja o uznaniu ich za pracowników podporządkowanych osobie lub podmiotowi zatrudniającemu jest uzależniona od ich pozycji w sferze organizacyjnej podmiotu, na rzecz którego

${ }^{9}$ Występuje tu gra słów, nie chodzi bowiem o rodzaj zawartej umowy, ale o warunki zatrudnienia sformułowane w każdej umowie o pracę, zarówno terminowej, jak i zawartej na czas nieokreślony. W polskim prawie pracy taką umowę nazywa się adhezyjną, do której (dotyczy to warunków pracy i wynagrodzenia) osoba ubiegająca się o pracę może przystąpić. 
świadczą pracę. Wyroki TSUE wydane w sprawach Danosa (C-232/09) i Balkaya (C-229/14) ukazują subtelne różnice w sytuacji prawnej osób zatrudnionych na najwyższych stanowiskach kierowniczych, uprawnionych do podejmowania decyzji niemal we wszystkich lub w większości kategorii spraw firmy. Dita Danosa, sprawująca funkcję dyrektora, wyłącznego udziałowca i jedynego członka zarządu spółki kapitałowej, pozostawała - zdaniem TSUE - w stosunku podporządkowania (relationship of subordination) względem przedsięwzięcia, jakim kierowała. Powyższe obowiązki mogła pełnić zarówno w roli osoby zatrudnionej na podstawie umowy cywilnoprawnej (kontraktu menedżerskiego) lub umowy o pracę regulowanej przepisami prawa pracy. W innej sytuacji - zdaniem TSUE - znajdowały się osoby zajmujące identyczne stanowiska kierownicze i mające pozycję w zarządzie instytucji zajmującej się szkoleniem zawodowym, a więc działalnością częściowo finansowaną z funduszy publicznych. Odmienności sytuacji prawnej podmiotu zatrudniającego odzwierciedlają zasadniczą różnicę w statusie osób zatrudnionych na stanowiskach kierowniczych. W instytucji niebędącej spółką kapitałową osoba zajmująca stanowisko dyrektorskie, pobierająca wynagrodzenie finansowane $\mathrm{z}$ funduszy publicznych, jest pracownikiem $\mathrm{w}$ rozumieniu przepisów wtórnego prawa unijnego, natomiast wyłączny akcjonariusz, członek jednoosobowego zarządu spółki kapitałowej, zajmujący stanowisko dyrektorskie, nie może być - według TSUE - potraktowany jako pracownik (worker) w rozumieniu przepisów unijnych, nie jest bowiem nikomu zawodowo podporządkowany, prowadzi działalność gospodarczą na własny rachunek. Jest więc niezależnym samozatrudnionym (C-107/94, P.H. Asscher versus Statssecretaries van Financien, EU:C:1996:251, § 26; C-337/97, C.P.M. Meeusen versus Hoofdirectie van den Informatie Beheer Groep, EU:C:1999:284, § 13), występującym w stosunku do innych osób będących pracownikami w charakterze pracodawcy. W pozostałych przypadkach unijna judykatura nie wyklucza możliwości uznania za pracownika osoby zatrudnionej na stanowisku kierowniczym nawet wówczas, gdy pozostaje ona w związkach rodzinnych z osobami sprawującymi nadzór merytoryczny nad wykonywaną przez nią działalnością zawodową (C-337/97, Meeusen, § 15). Powyższe stwierdzenie odnosi się również do osób zobowiązanych do zajmowania się sprawami organizacji społecznej z racji członkostwa. Wypracowana przez unijną judykaturę koncepcja „pracownika” (worker) ma zastosowanie wobec każdego zatrudnionego, którego w świetle judykatury TSUE, prezentowanej w niniejszym opracowaniu, można uznać, kierując się kryteriami sformułowanymi w orzecznictwie TSUE, za pracownika w rozumieniu przepisu art. 45 TFUE (C-216/15, Betriebsrat der Ruhrlandklinik GmbH versus Ruhrlandklinik GmbH, EU:C:2016:883).

Odpłatność, jako charakterystyczną cechę zatrudnienia pracowniczego, przedstawiam jako ostatni, ważny, aczkolwiek - moim zdaniem - nie najbardziej charakterystyczny element zatrudnienia pracowniczego. Odpłatnie bowiem wykonują pracę niemal wszyscy zatrudnieni. Także usługa polegająca na pracy 
wykonywanej w ramach działalności prowadzonej na własny rachunek lub na podstawie umów cywilnoprawnych jest z reguły opłacana. Porównując zatrudnienie pracownicze i niepracownicze, z pewnością można zakwalifikować brak wynagrodzenia za wykonaną pracę jako decydujący argument o zatrudnieniu niepracowniczym osoby, która tę pracę wykonywała. Porównując kryteria pozwalające odróżnić zatrudnienie pracownicze od niepracowniczego, zajmuję się więc wyłącznie pracą świadczoną za odpłatnością. Biorąc pod uwagę ten aspekt analizowanego zagadnienia prawnego, muszę - choć już wcześniej to zasygnalizowałem - dodać, że w prezentowanej judykaturze unijnej sposób wynagrodzenia za pracę nie ma wpływu na ocenę charakteru zatrudnienia: pracownicze - niepracownicze. Zatrudnienie uznane przez TSUE za pracownicze może być wynagradzane w każdej formie: pieniężnej (cash) oraz innych świadczeń materialnych i niematerialnych (kind), zarówno mających, jak niemających obiektywnej wartości (C-36/74, Walvare and Koch versus Association Union Cycliste International and Others, EU:C:1974:140, § 4, 10). Bez znaczenia jest również wysokość tych świadczeń oraz jej relacja w stosunku do nakładu energii zużytej na wykonanie pracy przez zatrudnionego. Przepisy traktatów (art. 39 TWE/art. 45 TFUE) nie ustanawiały żadnych zależności między wolnością przemieszczania się w obrębie wspólnego rynku a odpłatnością za różnego rodzaju świadczone usługi, również nieaprobowane przez część społeczności europejskiej (C-268/99, Aldona Małgorzata Jany and Others versus Staatssecretaries van Justitie, EU:C:2001:616, § 70).

\section{REFLEKSJA KOŃCOWA}

Unijna definicja pracownika ma charakter autonomiczny, a więc nie jest uzależniona od jakichkolwiek regulacji prawnych wprowadzonych przez władze państw członkowskich UE do krajowych systemów prawa pracy. Wyraził to bardzo dobitnie TSUE w orzeczeniu wydanym w sprawie Union syndicale Solidaires Isère (C-428/09, EU:C:2009:612), pisząc (cytuję w oryginale): „The sui generis legal nature of the employment relationship under national law cannot have any consequences in regard to whether or not the person is worker for the purpose of EU law". W rozumieniu traktatów unijnych pracownikiem jest - bez względu na stanowisko władz państwa członkowskiego UE - każda osoba świadcząca osobiście za wynagrodzeniem pracę na rzecz i pod kierownictwem innej osoby. Trybunał Sprawiedliwości, jako unijny organ wymiaru sprawiedliwości, sformułował kryteria pozwalające właściwym krajowym sądom pracy odróżnić zatrudnienie pracownicze od niepracowniczego. Można to uczynić w postępowaniu o uznanie za pracownika osoby zatrudnionej na podstawie umowy cywilnoprawnej oraz samozatrudnionego. Z punktu widzenia polskiego prawa pracy, materialnego i procesowego, współczesna unijna koncepcja pracownika jest zgodna $\mathrm{z}$ dotychczasową krajową tradycją legislacyjną oraz przepisami aktualnie obowiązującego Kodeksu pracy. 


\title{
BIBLIOGRAFIA
}

Bloch, Józef. 1936. Polskie ustawodawstwo społeczne, Kodeks pracy, ustawy, rozporządzenia, dekrety, orzecznictwo i komentarz. Warszawa: Druk. „Monolit”.

McCrudden, Christopher. 2012. „Two Views of Subordination: The Personal Scope of Employment Discrimination Law". Industrial Law Journal 41: 30-55.

Musiała, Anna. 2017. „Kim jest „pracownik” w ujęciu przepisów konstytucyjnych”. Monitor Prawa Pracy 4: 173-178.

Musiała, Anna. 2018. „Reperkusje pojęcia „worker” w polskim prawie pracy”. Monitor Prawa Pracy 5: 7-13.

Risak, Martin, Thomas Dullinger. 2018. The concept of 'worker' in EU Law. Status quo and potential for change. Report 140. Brussels.

Świątkowski, Andrzej Marian. 2014. „Autonomiczna definicja pracownika”. Monitor Prawa Pracy 11: $567-572$.

Świątkowski, Andrzej Marian. 2015a. „Prawo do wolności zrzeszania się i uprawnień pokrewnych”. Monitor Prawa Pracy 9: 454-461.

Świątkowski, Andrzej Marian. 2015b. W System prawa pracy. Cywilnoprawne zatrudnienie niepracownicze. Red. Krzysztof W. Baran. 47-160. Warszawa: Wolters Kluwer.

Świątkowski, Andrzej Marian. 2016. „Konstytucyjna koncepcja pracownika”. Monitor Prawa Pracy 1: 8-14.

Świątkowski, Andrzej Marian. 2018. „Szanse, zagrożenia i niewiadome zatrudnienia w stadium «czwartej rewolucji przemysłowej»". Polityka Społeczna 4: 1-9.

Terry, Michael, Linda Dickens. 1991. European Employment and Industrial Relations Glossary: United Kingdom. Dublin/Luxembourg: Sweet and Maxwell/Office for Official Publications of the European Communities.

\section{Andrzej Marian Świątkowski}

\section{RECOGNITION OF AN INDIVIDUAL EMPLOYED UNDER THE CIVIL LAW CONTRACT AS EMPLOYEE}

\begin{abstract}
The author presents unified concept of worker in the UE employment law. It includes all groups of active population who perform dependent, personally and economically, during the certain period of time services for and under the direction of another person in return of remuneration. Under that UE autonomous concept of employment any type of services, including self employment regulated by the civil law, is protected against major risks caused by the globalization and poverty.

Keywords: civil type of contract, dependency, economic activity, employment relationship, employer, employee, selfemployed, services, worker.
\end{abstract}

